\title{
A LINGUAGEM COMO METÁFORA EM GRAMSCI E A RELAÇÃO COM BRÉAL: UMA ABORDAGEM A PARTIR DA HISTÓRIA DAS IDEIAS LINGUÍSTICAS
}

\section{THE LANGUAGE AS METAPHOR IN GRAMSCI AND THE RELATION WITH BRÉAL: AN APPROACH THROUGH THE HISTORY OF LANGUAGE IDEAS}

\author{
Luciana Nogueira \\ Universidade do Vale do Sapucaí, Univás, Pouso Alegre, MG, Brasil \\ Renato César Ferreira Fernandes \\ Universidade Estadual de Campinas, Unicamp, Campinas, SP, Brasil
}

\begin{abstract}
Resumo: O presente trabalho é o resultado de uma pesquisa em andamento e que está em sua fase inicial. Assim, procuramos trazer o debate de um elemento não explorado no Brasil a partir do pensamento de Antonio Gramsci, a saber: a relação entre a linguagem e a metáfora presente em Cadernos do Cárcere. Para isso, abordamos a questão da linguagem como uma concepçáo de mundo, segundo o autor italiano, levando em conta as condiçóes sócio-históricas de produção de suas formulaçóes.
\end{abstract}

Palavras-chave: Linguagem; Metáfora; Antonio Gramsci; Michel Bréal; História das Ideias Linguísticas.

Abstract: The present work is the result of a research in progress and that is in its initial phase. Thus, we try to bring the debate of an element not explored in Brazil from the thought of Antonio Gramsci, namely: the relation between the language and the metaphor present in the Prison Notebooks. For this, we approach the question of language as a conception of the world, according to the Italian author, considering the socio-historical conditions of production of its formulations.

Keywords: Language; Metaphor; Antonio Gramsci; Michel Bréal; History of Language Ideas.

\section{Consideraçóes iniciais}

No presente trabalho ${ }^{1}$ buscamos promover um espaço de discussão

1 Uma versão mais resumida deste trabalho foi apresentada no Simpósio "Le discours et ses modes d'historicisation: entre le politique et le disciplinaire", organizado por Amanda Scherer, 
em torno de um elemento pouco explorado nas pesquisas sobre a obra de Antonio Gramsci no Brasil, a saber: a relação entre linguagem e metáfora presente em Cadernos do Cárcere. Trata-se de um trabalho em coautoria que implica numa parceria interdisciplinar, isto é, que envolve uma pesquisa a partir da História do Pensamento Político, por um lado, e da História das Ideias Linguísticas e da Análise de Discurso, por outro.

Iniciamos este percurso de pesquisa com um interesse em compreender a questão da relação entre linguagem e metáfora. Isto gerou desdobramentos como: i. o estudo do atravessamento de determinados linguistas nas elaboraçôes de Gramsci, como Bréal, por exemplo; ii. a compreensão do conceito de 'tradutibilidade' em Gramsci, no sentido de estabelecermos uma relação com a questão da metáfora; iii. o início de uma investigação de possíveis relações e contribuiçóes entre as concepçóes de Gramsci e as da Análise de Discurso e da História das Ideias Linguísticas tal como ela tem sido desenvolvida no Brasil.

\section{Elementos da biografia e da obra de Antonio Gramsci: as condiçóes de produçáo}

Na juventude, Antonio Gramsci (1891 - 1937) estudou linguística na universidade, principalmente glotologia e linguística histórica, mas não concluiu os estudos universitários em decorrência da militância política. Em 1919, recusou um convite para se tornar professor de Linguística na Universidade de Hamburgo ${ }^{2}$. Ao longo de seu percurso enquanto dirigente político, as questóes linguísticas interpelaram-no fortemente, desde as experiências e elaboraçóes acerca do movimento esperantista até seus últimos escritos, dedicados às questôes de gramática.

Gramsci foi preso em $1926^{3}$ e começou a escrever no cárcere em

Vanise Medeiros, Verli Petri e Cristiane Dias na Conférence Internationale d'Histoire des Sciences du Langage (14th International Conference on the History of the Language Sciences - ICHoLS $X I V$ ), realizada em Paris pelo Laboratoire d'Histoire des Théories Linguistiques e pela Société d'Histoire et d'Épistémologie des Sciences du Langage, como apoio da Université Paris Diderot, da Univesité Paris Sorbonne Nouvelle, do CNRS e do EFL LabEx.

2 A não aceitaçáo do posto acadêmico atesta, na verdade, que ele tinha significativa projeção acadêmica (não só política).

3 Antonio Gramsci foi preso em 08 de novembro de 1926. Durante o julgamento, em 1928, os acusadores do Ministério Público afirmaram sobre Gramsci que "por vinte anos devemos impedir que este cérebro funcione”. (FIORI, 1979, p. 285 apud BIANCHI, 2008, p. 21). Ele foi condenado a mais de vinte anos. 
1929. Muitos autores dividem a sua obra entre pré-carcerária e carcerária. Os escritos pré-carcerários tinham como preocupação fundamental a política em seu sentido mais imediato, de intervenção enquanto dirigente político. Isso não excluiu Gramsci de reflexôes não imediatamente políticas, como a crítica teatral e também as reflexóes sobre linguística. Uma das demonstraçóes disso é o artigo polêmico sobre o esperanto, de 1918, no qual critica a ideia da imposição de uma língua única, afirmando que "la difusión de una lengua particular depende estrechamente de la compleja actividad social del pueblo que la habla" (GRAMSCI, 2013, p. 54).

Essa preocupação linguística esteve presente também no período carcerário, no qual ele apresentou, em diversas notas esparsas, questóes sobre linguística, língua e filosofia. Tem um destaque especial o Caderno 29, reunindo notas escritas em 1935, com diversas reflexóes para um debate em relação à gramática, polemizando centralmente com as ideias desenvolvidas por Benedetto Croce no artigo Questa tavola rotonda è quadrata (1905).

Em suas cartas carcerárias, Gramsci afirmava que pretendia desenvolver uma obra "fürewig", isto é, "para sempre", uma obra que deixasse uma reflexão mais mediada sobre diversos temas (GRAMSCI, 2005, p. 128). É nesse sentido que a reflexão linguística aparece como tema em Gramsci: ele a considera relevante para uma reflexáo mais aprofundada e dedica parte dos seus escritos carcerários (cerca de 2000 mil páginas ao total), para realizá-la ${ }^{4}$.

A obra de Gramsci, no que diz respeito aos Cadernos, é bastante particular: são notas escritas pelo autor entre 1929-1935 para uma investigaçáo futura, para o desenvolvimento posterior de um pensamento mais geral. Algumas são reescritas, outras abandonadas e que nunca foram finalizadas. Algumas delas, como o próprio autor escreve, escritas sem as obras de referências. Esse caráter inconcluso e fragmentário marca textualmente todos os temas dos Cadernos e isso, a nosso ver, permite uma abertura ainda maior para diversas interpretaçôes e leituras possíveis da sua obra. Assim, a análise das condições de produção, principalmente dos elementos de constituição e o modo de formulação dos textos de Gramsci, é um ponto fundamental para o desenvolvimento de nossos trabalhos de pesquisa.

Nas últimas décadas, principalmente após a edição crítica italiana,

4 A primeira carta de Gramsci na prisão foi endereçada para a proprietária da casa que ele havia alugado. Além de desculpas sobre o transtorno causado, ele faz um pedido de envio de três livros para a prisão: uma Gramática Alemã, a Divina Comédia de Dante e o Breviario di linguistica de Bertoni e Bartoli, numa clara demonstração de seu interesse sobre o tema (GRAMSCI, 2005, p. 73). 
diversos pesquisadores investigaram as influências no pensamento de Antonio Gramsci como uma forma de compreender as suas elaboraçóes ${ }^{5}$, predominando aí um método de análise conhecido como filologia genética, a qual busca levar em consideraçáo o ritmo do desenvolvimento dos textos de Gramsci no cárcere como método de interpretação de Cadernos (FRANCIONI, 1984).

Vale dizer, ainda, uma nossa consideração, a saber, que trabalhar a presença ou o atravessamento de um autor sobre outro autor, de uma elaboraçáo sobre outra, implica lidar com dificuldades particulares e, no caso de Gramsci, específicas, pelas próprias condiçôes de produção dos seus textos (BIANCHI, 2008, p. 16).

\section{História das Ideias Linguísticas e Análise de Discurso}

Consideramos importante marcar a questão das filiaçóes teóricas. Nesse sentido, entendemos que essa é uma maneira de inscrição histórica do sujeito pesquisador, no caso, num certo processo de produção do conhecimento sobre a língua, que é constituído em nossa sociedade, na "sociedade do conhecimento", conforme a descreve Auroux (2008) ${ }^{6}$.

Estamos compreendendo a História das Ideias Linguísticas (HIL) numa relação com a Análise de Discurso, tal como esta é proposta e desenvolvida por Michel Pêcheux na França e Eni P. Orlandi no Brasil. Nesse sentido, retomamos a seguinte formulação de Orlandi:

São muitas as iniciativas de contar a história das ideias linguísticas, como diz S. Auroux (1989), desde o século XIX. De fato, podem-se classificar essas iniciativas em três categorias: a) a dos que visam constituir uma base documental para a pesquisa empírica; b) as que estâo em continuidade com uma prática de conhecimento da qual derivam (por exemplo, trabalho de um filólogo das línguas clássicas sobre a gramática, a filologia ou a gramática grega); c) as que têm papel fundador, que se voltam para o passado com a finalidade de legitimar uma prática científica contemporânea. Como é limitado, diz Auroux (idem), o ato de saber possui por definição uma espessura temporal, um horizonte de retrospecção, assim como um horizonte de projeção. Sem memória e sem projeto, diz ainda este autor (ibid.), simplesmente não há saber. Por isso é que, tomando a posição da análise de discurso, e pensando o conhecimento como um discurso (M. Pêcheux, 1975), podemos nos situar no ponto em que o sujeito desse

5 Conferir Areco \& Passos (2017).

6 Conferir Auroux (2008). 
conhecimento pode ser observado nesse seu horizonte de retrospecção e de projeção, e visamos assim não a reconstrução de uma história, mas o processo pelo qual ela se conta. Temos, dessa forma, a nossa contribuição específica e que é, em si, uma quarta categoria das iniciativas de se contar essa história (ORLANDI, 2002, p. 12).

Considerando isso, Dias (2012), que trabalha nessa perspectiva de uma HIL que estabelece relaçóes com a Análise de Discurso, apresenta uma relação entre a noção de interpretação para Orlandi (2007) e a sua compreensão do fazer HIL, justamente no sentido de permitir que se faça uma distinção metodológica entre a análise de discursos sobre o saber linguístico, seja por um dispositivo ideológico, seja por um dispositivo teórico. Para a autora:

\begin{abstract}
Alguns eixos de pesquisa em HIL, no Brasil, têm desenvolvido a tarefa de compreender a constituição do saber metalinguístico brasileiro e seus modos de institucionalização na sociedade pela produçáo e circulaçáa de instrumentos linguísticos. Nesse direcionamento, entendemos o fazer HIL na particularidade de se constituir por gestos de interpretaçáo determinados pelo dispositivo teórico da Análise de Discurso - como uma maneira de se "contar" uma história ao mesmo tempo em que se busca compreender o processo discursivo pelo qual é contada (DIAS, 2012, p. 24).
\end{abstract}

Nesse sentido, pensamos que, neste trabalho de sondagem de Cadernos, em busca de suas (re)formulaçóes sobre a linguagem, estamos, também, dando a ver o processo discursivo de como essa história de seu pensamento - político e linguístico, em sua (in)distinção - é produzida, é apagada, é destacada, é contada. Portanto, estamos de acordo com Dias (2012) quando ela afirma que, se a história, na Análise de Discurso, se liga sempre a práticas e a relações de poder (política) e de sentidos, é possível entender que há uma dualidade na especificidade do trabalho do analista de discurso que faz História das Ideias Linguísticas, a qual é assim explicitada:

de um lado, na relação com o texto, esse sujeito analista busca apreender a historicidade constitutiva do discurso na sua materialidade, em que, ao mesmo tempo que interpreta, ele descreve situando uma história no tempo; por outro lado, é pela compreensão dessa historicidade que ele é levado a discursivizar pela História das Ideias, o que é um modo de compreensão da própria história do conhecimento linguístico (DIAS, 2012, p. 25).

É o caso, por exemplo, de que fizemos referência anterior, da posição 
de Gramsci sobre o esperanto, sobre as questôes de gramática e sobre o debate acerca de questôes da linguística italiana (cf. NOGUEIRA \& FERNANDES, 2017a). Podemos, ainda, localizar essas formulaçóes e debates de Gramsci, não somente em relação à compreensão da linguagem como metáfora, mas também no que afirma Orlandi a respeito de como se "conta uma história". Vejamos:

Uma história se conta por acontecimentos, por fatos que irrompem do/ no cotidiano e que se marcam porque, ao se produzirem, fazem sentido, reclamam interpretação, demandam, como diz P. Henry, que lhe encontremos causas e consequências. E eu acrescentaria, como texto, essa história, com seus sentidos, tem de obedecer alguns princípios, entre os quais, e não menos importante, $\mathrm{o}$ da não-contradição.

Mas essa história é feita por homens. Que, nessa posição que estamos considerando, são autores de ciência e isto tem sua particularidade. Uma delas é a de comprometer-se, de um lado, com uma certa ordem de discurso e, de outro, com as instituiçóes tal como elas administram o conhecimento dentro de uma formação social, tomada na história (ORLANDI, 2000, s/p).

A autora considera, assim, que os discursos que falam de histórias são eles próprios parte da construçáo da memória e dos processos de identificação. Para ela, não há como contar uma história sem fazer recortes. E entâo é preciso dar visibilidade aos instrumentos com que esses recortes são produzidos (ORLANDI, 2000, s/p).

Estamos, com isso, de certa maneira, discursivizando a história de ideias linguísticas - de determinados saberes sobre a linguagem e como se representam esses saberes - de um pensamento político, buscando remeter às suas condiçôes de produção, com nosso gesto de interpretação. Para Dias (2012), esse gesto é determinado pela natureza do objeto de estudo e conclui a esse respeito que:

\footnotetext{
A História das Ideias Linguísticas consiste em uma possível maneira de se "contar" a história do conhecimento linguístico por gestos de interpretação, sobretudo, no sentido em que a interpretação se vincula com o arquivo, no qual temos a memória institucionalizada, que reclama por esses gestos (DIAS, 2012, p. 29).
}

Consideramos que houve deslocamentos produzidos no modo de compreender o objeto, e isso se deve, também, pelo fato de se ter um cientista político e uma analista de discurso produzindo conhecimento em 
HIL, ao mesmo tempo em que buscamos compreender essa produção de conhecimento.

\section{A linguagem como filosofia em Gramsci: a linguagem como metáfora}

Como dissemos, as elaboraçóes sobre a linguagem aparecem em diversas notas carcerárias, como nas questôes sobre: a unificação nacional italiana, a gramática, filosofia, na crítica às concepçôes linguísticas pragmatistas, entre outros.

Seguindo as definiçôes da linguística italiana de Matteo Bartoli, Gramsci distingue lingua e linguagem, ainda que, muitas vezes, os termos sejam usados como sinônimos. O trabalho com esses conceitos é diferente da clássica definição de Ferdinand de Saussure entre langue e langage. De acordo com Derek Boothman:

Em geral, Gramsci usa "linguagem" para denotar um subconjunto do fenômeno mais amplo de "língua", que, como tal, pode indicar o modo de falar ou de expressar de um grupo social (...) e também, no limite, dos indivíduos singulares. (...) De modo que a linguagem é geralmente de natureza setorial (BOOTHMAN, 2016, p. 476).

Nesse sentido, a língua aparece em Gramsci (2002, p. 180) como uma "concepção de mundo integral, e não apenas um vestido que de modo indiferenciado dá forma a qualquer conteúdo", sendo um "produto social" que é a "expressão cultural de um dado povo" (p. 196).

Desse modo, Gramsci debate a relação entre as linguagens, cultura e filosofia. Partindo da afirmação de que "todos os homens são filósofos", o autor concluiu que, pela "linguagem", todos os homens participam de uma "concepção de mundo", a linguagem como determinado modo de agir, pensar e sentir dos sujeitos. A linguagem é composta não por "palavras gramaticalmente vazias de conteúdo", mas por "um conjunto de noçôes e conceitos determinados" historicamente. Assim, Gramsci afirma que toda linguagem "contém os elementos de uma concepção do mundo e de uma cultura” (GRAMSCI, 1999, p. 93).

Nesse sentido, o processo de determinação dos sentidos é sempre uma relação dialética entre diversas "concepçôes de mundo" e a própria linguagem, de forma que, para Gramsci, é possível que um grupo social 
possa "apropriar-se da ciência de outro grupo sem aceitar sua ideologia" (p. 175). A formação dos sentidos das "palavras e das coisas" é fruto não de um processo natural, mas de um processo histórico de lutas políticas, ideológicas e sociais. É por isso que Gramsci converge com Bréal no sentido de que há uma "perpétua falta de proporção entre a palavra e a coisa" (BRÉAL, 2008, p. 81), isto é, as palavras não são fixas, mas históricas, mudam com o próprio processo político, social e cultural do qual elas são parte.

Partindo da linguagem, Gramsci propóe um caminho para a compreensão das concepçôes do mundo, ao mesmo tempo em que afirma que essas concepçóes são constituídas por meio de um processo metafórico: de apropriação e (re)significação determinadas pela luta política de hegemonias. Nesse sentido, "toda linguagem é um contínuo processo de metáforas, sendo a história da semântica um aspecto da história da cultura" (GRAMSCI, 1999, p. 156).

Porém, a relação entre a metáfora e a linguagem não é simples. De acordo com Gramsci,

\begin{abstract}
A linguagem é sempre metafórica. Talvez năo se possa dizer exatamente que todo discurso seja metafórico com relaçáo à coisa ou ao objeto material e sensível referido (ou ao conceito abstrato), a fim de não ampliar demasiadamente o conceito de metáfora; contudo, pode-se dizer que a linguagem atual é metafórica com relação aos significados e ao conteúdo ideológico que as palavras tiveram nos períodos anteriores da civilização (GRAMSCI, 1999, p. 145).
\end{abstract}

É nessa discussão, da linguagem como metáfora, que a referência a Michel Bréal aparece em Gramsci, que vai afirmar que o tratado de semântica de Bréal, por exemplo, "pode fornecer um catálogo, histórica e criticamente reconstruído, das mutaçóes semânticas de determinados grupos de palavras" (GRAMSCI, 1999, p. 145). O problema aqui é que não se trata somente de "exemplos" de metáforas. Nossa hipótese é que há, em Gramsci, por meio do debate acerca da linguística italiana, uma recuperação da compreensão historicista de Bréal para a compreensão da linguagem e, consequentemente, da filosofia.

\title{
A presença de Bréal em Gramsci ${ }^{7}$
}

7 Com relaçáo a este tema, apresentamos trabalho ("A língua como um museu de metáforas: a influência de Michel Bréal em Antonio Gramsci) no Colóquio Internacional Antonio Gramsci, em Campinas, Unicamp, em 2017. Conferir Nogueira e Fernandes (2017b). 
Entre os autores que fazem referência à relação entre Gramsci e Bréal está Alessandro Carlucci. Ele destacou que o linguista foi uma influência importante dos estudos de Gramsci, assim como outros linguistas italianos de sua época (CARLUCCI, 2013, p. 9). Essa aproximação feita pelo autor procura aprofundar a afirmação de outro linguista italiano, Giancarlo Schirru, o qual afirmou que a análise da mudança linguística em Gramsci, principalmente nas determinaçóes verticais (como de classe, dominação política, etc.), sofreu a "mediação da linguística histórica francesa" (SCHIRRU, 2008, p. 418).

No debate sobre a análise das metáforas, Gramsci cita o Ensaio de Semântica de Bréal. De acordo com Schirru, talvez o Ensaio seja o livro que mais influenciou suas formulaçóes sobre a linguagem no cárcere. Para nós, Bréal é uma das fontes de elaboraçáo da metodologia gramsciana para a reflexão sobre a língua, a linguagem e a filosofia.

Há muitas convergências entre Bréal e Gramsci, como, por exemplo, o método historicista de ambos, a consideraçáo de que há as transformaçôes semânticas por meio das metáforas e o papel dos intelectuais em sentido amplo (poetas, cientistas, jornalistas, etc.) nesse processo de mudança da linguagem na história.

No que diz respeito à linguística de Bréal, Ana Zandwais afirma que:

\begin{abstract}
Cabe também observar que, para Bréal, a linguagem ordinária precisa ser analisada não somente como um dado, estático, mas, sobretudo, em termos de seus processos de transformaçáo porque aquilo que a transforma é o que a torna dinâmica, viva. Deste modo, seria tarefa essencial do investigador olhar para os fatos de linguagem e, ao mesmo tempo, para as suas transformaçóes, sem estar simplesmente fundamentado em relaçóes de base dedutiva, calcadas nas observaçóes estritas das mudanças, dos deslocamentos que podem ocorrer em suas estruturas internas, já que, segundo Bréal, "a lógica popular”, que pode ser entendida como o motor que move a língua, avança em etapas nem sempre visíveis para o filólogo ou para o linguista (ZANDWAIS, 2013, p. 50).
\end{abstract}

Essa dialética entre a historicidade da linguagem e o processo de transformação semântico calcado na vida social é a base para a compreensão brealiana das metáforas. Sua formulação sobre a metáfora como "mudança de uma ordem de ideias para outra ordem de ideias" parece-nos que converge com o conceito de tradutibilidade em Gramsci, isto é, leva-nos a 
pensar que temos aí as bases "nocionais" para o que Gramsci vai formular como o processo de tradutibilidade, o qual não implica na ideia de tradução linguística empírica.

Em Ensaios, Bréal analisa "como se fixou os sentidos das palavras", a partir de uma compreensão historicista. Para isto, ele vai analisar os diversos fatores de mudança dos sentidos das palavras, afirmando que é o próprio processo histórico e social que fixa e transforma os sentidos das palavras (BRÉAL, 2008, p. 79).

É desse modo que Bréal analisa as metáforas. Para ele, "a metáfora muda instantaneamente o sentido das palavras, cria expressóes novas de um modo súbito" (BRÉAL, 2008, p. 91). Ela pode representar uma semelhança entre dois objetos, dois atos ou fazer nascer uma semelhança, podendo ocupar uma lacuna no vocabulário. Para Bréal, o conflito entre o "tropos da linguagem e as metáforas dos poetas" é uma das causas da transformaçấo da linguagem, do surgimento de novas palavras, etc.

Dessa forma, os intelectuais têm um papel imenso nessa transformação, já que são eles, na sociedade moderna, muitas vezes, os criadores das novas metáforas. Essa criação tem justamente como base a necessidade de se expressar o novo com uma outra linguagem, com outras palavras, com a transformação dos sentidos: "a imaginação" necessita "transpor uma palavra de uma ordem de ideias para outra” (BRÉAL, 2008, p. 94).

Dado essa potência da metáfora na transformação da linguagem, Bréal afirma que "todas as línguas poderiam assim constituir seu museu das metáforas” (BRÉAL, 2008, p. 94), muito próximo do que ele próprio faz em seu Ensaio, mas também muito próximo à afirmação de Gramsci de que "a linguagem é, simultaneamente, uma coisa viva e um museu de fósseis da vida e das civilizaçôes passadas" (GRAMSCI, p. 156). E, nessa perspectiva, essas novas metáforas, os novos sentidos e usos das palavras, devem ser compreendidos no contexto histórico e cultural do qual fazem parte.

\section{Gramsci e as metáforas: uma interpretaçáo brealiana?}

As afirmaçôes de Gramsci sobre a linguagem e as metáforas parecemnos como uma radicalização da concepção de Bréal. Radicalização, pois, enquanto Bréal analisa a produçáo do sentido de maneira historicista, com suas determinaçóes políticas e sociais, sendo a metáfora uma parte desta transformaçáo, Gramsci afirma que a "linguagem é sempre metafórica". Isto 
é, a metáfora é base para todas as transformações da linguagem.

Para entender essas transformaçôes, vamos recuperar algumas análises que Gramsci realiza de termos do materialismo histórico e seus significados. Nessas análises, aparecem de forma melhor desenvolvida a metodologia que ele utiliza para compreender os sentidos das palavras e a transformação metafórica da linguagem.

$\mathrm{Na}$ análise das metáforas marxianas, Gramsci tem como principal interlocutor Nikolai Bukharin. Para ele, era "necessário observar que se encontramos algumas vezes em Marx e Engels definiçóes, que tem aparência exterior das condiçôes teleológicas, isto não constitui senão uma metáfora e uma maneira de exprimir um pensamento por imagens" (BUKHARIN, s/d, p. 25). Nessa tese, Bukharin considera a utilização das metáforas apenas como "representação por imagens", isto é, somente uma figuração das ideias. Será na polêmica com essa concepção que Gramsci vai analisar as metáforas marxianas.

Numa nota intitulada História da terminologia e das metáforas, Gramsci se propôe a analisar o termo "anatomia" utilizado por Marx na seguinte passagem dos Grundrisse:

\begin{abstract}
A anatomia do ser humano é uma chave para a anatomia do macaco. Por outro lado, os indícios de formas superiores nas espécies animais inferiores só podem ser compreendidos quando a própria forma superior já é conhecida. Do mesmo modo, a economia burguesa fornece a chave da economia antiga etc. Mas de modo algum à moda dos economistas, que apagam todas as diferenças históricas e veem a sociedade burguesa em todas as formas de sociedade (MARX, 2011, p. 58).
\end{abstract}

No fragmento do texto de Marx é possível fazer a seguinte sinonímia: "a anatomia da economia burguesa é a chave da economia antiga". A primeira questáo nessa sinonímia é responder: a anatomia na ciência biológica tem o mesmo sentido na ciência crítica marxista? Isto é, ao transferir o conceito de uma ciência para outra, não se transforma também o sentido? Na ciência biológica, a utilizaçáo do termo "anatomia" significou um avanço científico, já que começou a diferenciar as espécies não mais por características secundárias e acidentais, de acordo com Gramsci. Para ele, a justificativa da utilização da metáfora "anatomia" tem um sentido de "popularização" da ciência marxista por meio da formulação de "um esquema de fácil compreensão" (GRAMSCI, 1999, p. 191). No entanto, essa popularização fez com que, muitas vezes, se recorresse a metáforas por 
vezes "grosseiras e violentas". Aqui temos uma possível crítica de Gramsci que não é desenvolvida. De acordo com Peter Ives, colocando a metáfora da "anatomia" em seu contexto, "Gramsci defende que o uso marxiano da metáfora biológica talvez não seja apropriado, uma vez que esta, no final das contas, reforça o determinismo econômico" (IVES, 2017, p. 531).

Para Gramsci, na formulação da ciência e da filosofia, é possível "apropriar-se da ciência de outro grupo sem aceitar sua ideologia" (GRAMSCI, 1999, p. 175). Aqui ele faz referência direta entre o marxismo e a teoria evolucionista: é possível apropriar-se da teoria da evolução sem aceitar a ideologia evolucionista vulgar. Isso só é possível para o autor, pois a ciência não é somente um método de análise da realidade, mas também a combinação entre este método, o objeto e as hipóteses construídas. É essa diferenciação que permite a apropriação, muitas vezes metafóricas, da linguagem de uma ciência por outra ciência. É esta base metodológica que permite Gramsci interpretar as metáforas de Marx e também desenvolver o conceito de tradutibilidade.

A compreensão das metáforas deve se dar a partir de um "estudo da origem linguístico-cultural”, no próprio sentido dado por Bréal em seu Ensaio de Semântica. Esse estudo pode ajudar a compreender melhor o próprio conceito, na medida em que ele é relacionado ao mundo cultural, historicamente determinado, do qual surgiu, bem como é útil para determinar o limite da própria metáfora, de seus sentidos, etc. (2008, p. 191).

Para explicar as razóes que levaram Marx (e, em outras ocasióes, Engels) a empregar metáforas das ciências naturais na sua explicação histórica e social, Gramsci afirma que, na época, as ciências naturais eram o "modelo" de ciências, e as ciências sociais queriam "encontrar um fundamento objetivo e cientificamente capaz de lhes fornecer a mesma segurança e energia das ciências naturais" (2008, p. 191). Em sua interpretação, o emprego do conceito de "anatomia" relaciona-se à questão da legitimação do discurso científico.

Numa nota intitulada Questôes de nomenclatura e conteúdo, Gramsci procura explicitar a relaçáo entre uma nova camada de intelectuais e sua relação com a camada de intelectuais precedentes. Ele afirma que, na esfera ideológica, "uma idêntica nomenclatura de conceitos" (GRAMSCI, 1999, p. 125) demonstra justamente a unidade entre a velha e a nova camada de intelectuais de uma sociedade. Contudo, com a transformação da sociedade e o desenvolvimento dessa camada de intelectuais, é quase sempre provável 
que haja uma transformação dos conceitos, seja em sua forma, seja em seu significado. Em relação a isso, Gramsci afirmou que:

\begin{abstract}
Todavia, deve-se levar em conta que nenhuma nova situação histórica, mesmo a derivada da mudança mais radical, transforma completamente a linguagem, pelo menos em seu aspecto exterior, formal. Mas o conteúdo da linguagem deveria ter mudado, ainda que seja difícil, de imediato, ter consciência exata desta modificação. Por outro lado, o fenômeno é historicamente complexo e se complica graças à existência de diversas culturas típicas nos diversos estratos do novo grupo social, alguns dos quais, no terreno ideológico, ainda estão imersos na cultura de situaçóes históricas que precedem, às vezes, até mesmo aquela que foi superada mais recentemente (GRAMSCI, 1999, p. 125).
\end{abstract}

Duas consequências podem ser tiradas dessas afirmaçóes de Gramsci. A primeira é que uma nova situação histórica (pós-revolução francesa ou russa, por exemplo) é atravessada por um processo objetivo de transformação dos sentidos na linguagem e também das palavras. Mas, o mais interessante é que justamente a mudança de sentido é mais provável, mesmo que de maneira não planejada, inconsciente, do que a mudança das palavras da linguagem: no processo revolucionário; poderíamos acrescentar, ainda, que, no próprio processo histórico, o tempo semântico da linguagem se modifica mais rápido do que o tempo ortográfico.

Esse parece ter sido o exemplo do termo materialismo com relaçáo às transformaçóes operadas no conceito por Marx e Engels. Em seu Tratado, Bukharin aproxima o materialismo histórico dos antigos materialismos grego e francês. Gramsci rejeita essa aproximação. A primeira crítica se relaciona à "redução do materialismo histórico ao materialismo metafísico" (2008, p. 128). E é nessa crítica que afirma que a "Identidade de termos não significa identidade de conceitos" (2008, p. 128). Ao colocar em relevo a diferença entre "termos" e "conceitos", Gramsci procura afirmar justamente que a utilização do termo "materialismo" por Marx e Engels não tem a mesma definição conceitual que o materialismo nos autores anteriores a ele. Para compreender o sentido do termo empregado pelos fundadores do materialismo histórico, é necessário um estudo mais amplo, "linguísticocultural", das razóes que os levaram a utilizarem o termo, conforme Gramsci.

A partir dessa diferenciação, Gramsci recupera a obra de Friederich Lange, História do Materialismo. Essa é uma obra curiosa para Gramsci: escrita em 1866, Lange buscou sistematizar os princípios básicos do pensamento 
materialista ao longo da história e, de acordo com essa classificação, excluiu Ludwig Feuerbach e Karl Marx da tradiçáo materialista. Mas, ao mesmo tempo em que excluía Marx da tradição materialista, essa obra inspirou diversos marxistas a interpretar a filosofia materialista de Marx. Nesse sentido, Gramsci acrescenta que, para a compreensão de um "conceito" de um autor, "é sempre necessário recorrer às fontes culturais para determinar o valor exato dos conceitos, já que, sob um mesmo chapéu, podem estar diferentes cabeças" (2008, p. 129). Isto é, uma análise do conceito "materialismo" em Marx e Engels demonstraria o quanto esses estão longe do materialismo mecanicista, ainda que empreguem o mesmo termo. É neste sentido metafórico que podemos afirmar que há a "substituição de um sentido por outro".

Também os conceitos de "imanência" e "imanente" são postos em questáo por Gramsci no debate com Bukharin. Ambos conceitos são utilizados por Marx a partir de uma apropriação da linguagem filosófica idealista que concebe a presença de Deus no mundo real como imanente. Assim, criticando Bukharin, Gramsci afirma que:

\begin{abstract}
No Ensaio ${ }^{8}$, observa-se que os termos "imanência" e "imanente" são usados na filosofia da práxis, mas que — "evidentemente" - este uso é apenas "metafórico". Muito bem. Mas, com isso, explicou-se o que significam "metaforicamente" imanência e imanente? Por que estes termos continuam sendo usados e náo são substituídos? Tăo-só pelo horror de criar novos vocábulos? Com frequência, quando uma nova concepção sucede uma anterior, a linguagem precedente continua a ser usada, mas precisamente de maneira metafórica. Toda a linguagem é um contínuo processo de metáforas, sendo a história da semântica um aspecto da história da cultura: a linguagem é, simultaneamente, uma coisa viva e um museu de fósseis da vida e das civilizaçóes passadas (GRAMSCI, 1999, p. 156, grifos nossos).
\end{abstract}

Como dissemos na comparação com Bréal, o fato de a linguagem ser ao mesmo tempo "viva" e um "fóssil" é a contradição do próprio processo linguístico: ela traz a marca do passado, seja pelas palavras, seja pelo sentido produzido; mas, ao mesmo tempo, ela é transformada a todo momento, junto e autonomamente da cultura, da história. São os grupos sociais em movimento, as lutas culturais, as lutas políticas, as influências de línguas estrangeiras, etc., que permitem essa "vida" para a linguagem, ao mesmo

8 Faz referência a obra Tratado de Materialismo Histórico que tem como subtítulo original Ensaio popular de sociologia marxista. 
tempo em que deixam marcas, que volta e meia aparecem no discurso dos sujeitos.

Essa forma de analisar a metáfora demonstra, para nós, uma apropriaçáo e uma continuidade teórica sobre o tema entre o Ensaio de Semântica de Michel Bréal e a linguística gramsciana. Essa compreensão não está somente na referência, mas também na metodologia para compreender as metáforas e as transformaçôes linguísticas por meio da análise historicista e cultural. Dessa forma, torna-se importante incorporar Bréal como uma das influências do pensamento gramsciano, principalmente para a compreensão de sua análise da linguagem. Mas náo só da análise linguística, já que as "reflexôes linguísticas de Gramsci formam uma parte integral de seu trabalho político e intelectual e elas necessitam ser estudadas dessa forma" (CARLUCCI, 2013, p. 2, tradução nossa).

Nos estudos das metáforas marxianas que nos referimos anteriormente, há uma crítica metodológica à compreensão da identificação entre os termos de Marx e de filósofos e economistas que foram fontes para sua elaboraçáo. Nessa crítica de Gramsci, há uma proposta metodológica que pode ser estendida para a análise dos conceitos em outros autores: a necessidade de se incorporar uma análise crítica, linguística e cultural para entender a localização dos conceitos e o processo metafórico. Para nós, é na análise das condiçôes de produção do discurso que se interpreta os próprios conceitos.

Essa crítica nos leva a pensar também na interpretação do próprio Gramsci, afinal, seus Cadernos estão atravessados por conceitos e metáforas, como Oriente, Ocidente, Guerra de posição e de manobra, etc., levandonos a refletir a relação entre metáfora e interdiscurso, numa tentativa de aproximar Gramsci da Análise de Discurso?.

\section{Michel Pêcheux: Metáfora e (Efeito de) Interdiscurso}

Pêcheux ([1975] 1995) afirma que "a metáfora está na base da significaçáo", formulação base que nos faz estabelecer a relação entre os autores neste artigo. Com Orlandi, temos a concepção de que a metáfora é entendida como efeito de uma relação significante (LACAN, 1966) ${ }^{10}$ :

9 Quanto a essa via de desenvolvimento deste trabalho de pesquisa, estamos produzindo um outro texto em que a questão da tradutibilidade em Gramsci é posta em relação à metáfora e como isso pode ser pensado com a Análise de Discurso, a partir do que trata Pêcheux (2011) em seu texto Metáfora e Interdiscurso.

10 A referência que Orlandi (2007) faz a Lacan é a seguinte: LACAN, J. Écrits. Paris: 
uma palavra por outra. Os sentidos só existem nas relaçôes de metáfora e são produzidos em certa formação discursiva, a qual é o seu lugar mais ou menos provisório. Desse modo, o lugar do sentido, que é lugar da metáfora, é função da interpretação e é espaço da ideologia (ORLANDI, 2007).

Podemos, nesse sentido, pensar em algumas relações (im)possíveis entre Gramsci e Pêcheux, quanto ao lugar que tem a metáfora nas elaboraçôes desses autores. Partimos de um texto de Pêcheux intitulado Metáfora e Interdiscurso (2011). Nele, o autor aponta que há uma crítica a uma suposta "sociologia do saber", que pressupóe precisamente a existência evidente dos objetos de saber ignorando os "processos discursivos" nos quais eles se constroem (PÊCHEUX, 2011, p. 152). Deixando essa afirmação apenas como uma pontuaçáo, a qual é desenvolvida no texto em questão pelo autor, agregamos outra, que é a crítica de um pressuposto filosófico comum a duas perspectivas: semântica e pragmática - como ele denomina que é o de ser uma antropologia a-histórica da subjetividade fundada desde o início na noção de sujeito. Com isso, Pêcheux, retomando Kleist, refere que isso dá ao problema posto por ele a forma de uma separação (pessoas que se compreendem através das fórmulas) ou de uma integraçáo (pessoas que se compreendem através de metáforas). E, considerando que:

\begin{abstract}
Talvez nosso objeto de pesquisa encontra-se precisamente nas formas de circulação que se instauraram historicamente entre essas diversas zonas discursivas e que se transformaram consideravelmente ao longo do tempo: é entâo preciso retroceder até a questão da produção discursiva do sentido de um enunciado (expressão, frase ou sequência textual mais importante), e é efetivamente o que H. U. Gumbrecht e J. Link, a meu ver, empreenderam, por vias relativamente diferentes (PÊCHEUX, 2011, p. 152-153).
\end{abstract}

Pêcheux deixa em suspenso essa discussão de pressupostos filosóficos e passa para o que ele denomina de "dificuldades de fato". Fixamo-nos aqui na primeira dificuldade por ele apontada:

- a primeira dificuldade reside no fato, aliás bastante constatado que as teorias científicas nâo se desenvolvem nunca no espaço puro do discurso lógico, mas se estabelecem sempre sobre uma rede metafórica que lhes serve de apoio: a constituição de Sachverhalte científicas (e mais geralmente dos objetos de saber) não é pois dissociável dos efeitos metafóricos, que não podemos, assim, restringir ao espaço "subjetivo" do vivido cotidiano ou da poesia (PÊCHEUX, 2011, p. 154-155, grifos nossos).

Seuil, 1966. 
Essa perspectiva de que as teorias científicas estabelecem-se sempre sobre uma rede metafórica que lhes serve de apoio por meio de "efeitos metafóricos" tem uma relação muito direta com o que afirma Gramsci na relação entre as diversas filosofias, inclusive das metáforas de Marx: é sobre a apropriação da linguagem desenvolvida em outras filosofias que se desenvolvem as novas concepçóes de mundo.

Pêcheux, referindo-se à noção de formação discursiva introduzida por Foucault, afirma que ela permite que se tirem conclusôes críticas importantes, sendo uma delas considerar "uma concepção materialista da discursividade na qual os efeitos do interdiscurso náo se resolvem em um ponto de integração, mas se desenvolvem em contradiçóes" (2011, p. 157).

\begin{abstract}
Nessa perspectiva, o interdiscurso, longe de ser efeito integrador da discursividade torna-se desde então seu princípio de funcionamento: é porque os elementos da sequência textual, funcionando em uma formaçáo discursiva dada, podem ser importados (meta-forizados) de uma sequência pertencente a uma outra formaçáo discursiva que as referências discursivas podem se construir e se deslocar historicamente (PÊCHEUX, 2011, p. 158).
\end{abstract}

O que propomos aqui é considerar uma certa filiação teórica em que podemos pensar juntos esses autores que dão lugar privilegiado à metáfora na linguagem. Náo só um lugar privilegiado, mas o reconhecimento de que ela está na base da significação, de que a linguagem é metafórica por excelência.

\title{
Consideraçóes Finais
}

Nossa retomada do caminho traçado por Gramsci inscreve-se numa tentativa de contribuir para uma análise materialista das questóes em torno da linguagem e da HIL, considerando a história das práticas científicas e da produção e circulação do conhecimento, levando em conta suas condiçóes materiais de existência, o que implica pensar na produção e delimitaçáo de certos conhecimentos científicos e da constituição por meio da linguagem, de “concepções de mundo". Portanto, as questôes que trazemos à reflexão estão integralmente postas no campo da linguagem, por um lado, e integralmente postas no campo das condiçôes históricas, por outro.

Considerando toda essa elaboração em vai e vem de disciplinas teóricas 
e leituras políticas, avaliamos pertinente concluir com esta afirmação:

\begin{abstract}
Eu gostaria que, marxistas ou náo, sejamos capazes de frustrar, em nosso domínio de investigação e de reflexão, a irresistível tendência ao narcisismo teórico que pode tomar diversas formas integrativas, entre a a-historicidade antropológica e a historicidade homogênea de um simbolismo coletivo que parece ter dificuldades em suportar a categoria de contradiçẫo (PÊCHEUX, 2011, p. 161)
\end{abstract}

Ou seja, é com esse propósito que tentamos conduzir nosso trabalho, mesmo sabendo que não escapamos disso. A parceria dá a ver tensôes que são próprias disso que fala Pêcheux, mas também impulsiona a ir além na pesquisa. Há temas nessa relação que devem ser aprofundados, como, por exemplo, a questáo da relaçáo entre a metáfora e a tradutibilidade "das linguagens".

\title{
Referências
}

ARECO, S.; PASSOS, R. Gramsci e seus contemporâneos. São Paulo: Cultura Acadêmica, 2017.

AUROUX, S. A questáo sobre a origem das línguas seguido de A historicidade das ciências. Campinas: Editora RG, 2008.

BIANCHI, Á. O laboratório de Gramsci: Filosofia, história e política. São Paulo: Alameda, 2008.

BRÉAL, M. Ensaio de Semântica. 2. ed. Campinas: RG, 2008.

BOOTHMAN, D. Língua. In.: LIGUORI, Guido; VOZA, Pasquale (Orgs.). Dicionário gramsciano (1926-1937). São Paulo: Boitempo, 2017. p. 475-476.

BOOTHMAN, D. Linguagem. In.: LIGUORI, Guido; VOZA, Pasquale (Orgs.). Dicionário gramsciano (1926-1937). São Paulo: Boitempo, 2017. p. 476-478. 
BUKHARIN, N. Tratado de Materialismo Histórico. Lisboa: CLB, Sem data.

DIAS, J. P. Um Gesto de Interpretaçáo na História do Conhecimento Linguístico Brasileiro: a definiçẫo do nome gramática. 2012. Tese (Doutorado em Letras) - Universidade Federal de Santa Maria, Santa Maria, 2012.

CARLUCCI, A. Gramsci and Languages. Leiden: Brill, 2013.

CROCE, B. Questa tavola rotonda è quadrata. La Critica, v. 3, p. 531-534, 1905.

FRANCIONI, G. L'officina gramsciana: ipotesi sulla struttura dei "Quaderni del carcere". Nápoles: Bibliopolis, 1984.

GRAMSCI, A. Cadernos do cárcere. Rio de Janeiro: Civilização Brasileira, v. 1-6, 1999-2002.

GRAMSCI, A. La lengua única y el esperanto. Escritos sobre ellenguaje. Buenos Aires: Eduntref, p. 53-58, 2013.

IVES, P. Metáfora. In.: LIGUORI, Guido; VOZA, Pasquale (Orgs.). Dicionário gramsciano (1926-1937). São Paulo: Boitempo, 2017, 2017. p. $530-532$.

MARX, K. Grundrisse. São Paulo: Boitempo, 2011.

NOGUEIRA, L.; FERNANDES, R. C. F. Linguagem e metáfora nos Cadernos do Cárcere de Antonio Gramsci. Entremeios, v. 14, p. 167-181, 2017a.

NOGUEIRA, L.; FERNANDES, R. C. F. A língua como um museu de metáforas: a influência de Michel Bréal em Antonio Gramsci. 
Paper apresentado no Colóquio Antonio Gramsci, Campinas, agosto de 2017b. Disponível em: <https://drive.google.com/file/ d/0BwD7_494xHN2MXVQUWpIQnBnWjA/view>. Acesso em: out. 2018.

ORLANDI, E. P. Um fato, um acontecimento, uma história: idéias linguísticas no Brasil. Relatos. Campinas, n. 6, n.p., 2000. Disponível em: <http.://www.unicamp.br/iel/hil/publica/relatos_06.html>. Acesso em: 11 abr. 2018.

. Língua e Conhecimento Linguístico: para uma História das Ideias no Brasil. São Paulo: Cortez, 2002.

Interpretaçáo: autoria, leitura e efeitos do trabalho simbólico. Campinas: Pontes, 2007.

PÊCHEUX, M. Semântica e Discurso: uma crítica à afirmação do óbvio. 2. ed. Campinas: Editora da Unicamp, [1975]1995.

. Metáfora e Interdiscurso. In: Análise de Discurso - Michel Pêcheux: Textos Escolhidos por Eni Puccinelli Orlandi. Campinas: Pontes, 2011. p. 151-161.

SCHIRRU, G. La categoria di egemonia e il pensiero linguistico di Antonio Gramsci. In: D’Orsi, Angelo (Org.). Egemonie. Napoli: Dante \& Descartes, 2008. p. 397-444.

ZANDWAIS, A. O Funcionamento da Subjetividade: um contraponto entre estudos comparatistas e a filosofia da linguagem russo-soviética. Conexáo Letras, v. 10, p. 47-5, 2013. 